unsuitable for training junior ophthalmologists, although a recent wide ranging review of staffing in ophthalmology suggested that use of specially trained clinical assistants or long term senior house officers for surgery and outpatient follow up should be considered."

The Audit Commission has noted how widely the rates of day case cataract surgery vary in Britain, with many districts doing none and others treating more than $40 \%$ of their cataracts this way. ${ }^{12}$ It has therefore recommended $20 \%$ as an optimistic target for the proportion of cataracts to be treated by day case surgery. With adequately resourced units this target seems achievable. To tackle the backlog of cataract surgery (about 65000 cases in 1991) other measures such as local initiatives may also be required. ${ }^{13}$

The demands for ophthalmic services will continue to rise as the number of elderly people increases, the threshold for surgical intervention falls, ${ }^{14}$ and developments such as refractive surgery and complex vitreoretinal surgery occur in other aspects of treatment. More ophthalmologists need appointing: the number of ophthalmologists per head in Britain is among the lowest in Europe and much lower than that in the United States. The College of Ophthalmologists has recommended the creation of 200 new consultant posts if Britain is to have a proper hospital eye service. ${ }^{13}$ The college has taken a positive attitude to day case surgery and better integration with primary care, and this positive approach should be matched by the provision of adequate resources in provider units.
Cataract surgery with intraocular lens implantation is probably the most successful microsurgical procedure in modern medicine. We owe it to our elderly population to make it more widely available.

HUGH F THOMAS Senior Registrar in Public Health Medicine

ROGER HUMPHRY

Salisbury Health Authority, Consultant Ophthalmologist

Odstock Hospital,

Salisbury SP2 8BJ

1 College of Ophthalmologists Audit Commission. National cataract survey. Preliminary report. Glasgow: College of Ophthalmologists, 1991.

2 Ingram RM, Banerjee D, Traynar MJ, Thompson RK. Daycase cataract surgery. Br f Ophthalmol 1983;67:278-81.

3 Davies PD, Limacher E, Powell K. Outpatient cataract surgery 1982-1986. Eye 1987;1:728-34.

4 Strong NP, Wigmore W, Smithson S, Rhodes S, Woodruff G, Rosenthal AR. Day-case cataract surgery. Brf Ophthalmol 1991;75:731-3.

5 Percival SPB, Setty S. Prospective audit comparing ambulatory day surgery with inpatient surgery for treating cataracts. Quality in Health Care 1992;1:38-42.

6 Lowe KJ, Gregory PA, Jeffrey RI, Easty DL. Patient perceptions and social impact: Preliminary results of the Bristol MRC survey. Eye 1991;5:373-8.

7 Davies B, Tyers AG. Do patients like day case cataract surgery? Br 7 Ophthalmol 1992;76:262-3.

8 Watts MJ, Pearce JL. Day-case cataract surgery. Br $\mathcal{J}$ Ophthalmol 1988;72:897-9.

9 Atkinson WS. Development of ophthalmic anaesthesia. Am $\mathcal{J}$ Ophthalmol 1961;51:1-14.

10 Leaver P. Prospects for day case vitreo-retinal surgery. Br $\mathcal{F}$ Ophthalmol 1992;76:65.

11 Dowie R. Patlerns of hospital medical staffing. Ophthalmology. British Postgraduate Medical Federation. London: HMSO, 1991.

12 Audit Commission for Local Authorities and NHS in England and Wales. A short cut to better services: day surgery in England and Wales. London: HMSO, 1990.

13 Drummond MF, Yates JM. Clearing the cataract backlog in a (not so) developing country. Eye $1991 ; 5: 481-6$.

14 Batterbury M, Khaw PT, Hands R, Elkington AR. The cataract explosion: the changing pattern of diagnoses of patients attending an ophthalmic outpatient department. Eye 1991;5:369-72.

\title{
Liver fibrosis
}

\section{Better understanding may help diagnosis and treatment}

Hepatic fibrosis is a common sequel to most forms of chronic liver disease and an essential component in the development of cirrhosis. Even without cirrhosis, fibrosis may disrupt intrahepatic blood flow and produce portal hypertension. Recent interest in the basic cellular and molecular mechanisms of fibrogenesis is beginning to pay dividends in clinical hepatology, suggesting new approaches to diagnosis and treatment.

Far from being a passive aggregation of "reticulin", fibrosis is now seen to be a dynamic process, resulting in the accumulation of several distinct proteins in the extracellular matrix. ${ }^{2}$ The effect of this accumulation is not simply to create a space occupying mass; by changing the composition of the extracellular matrix, fibrosis may directly alter hepatocyte function via cellular integrins. These proteins act as transmembrane linkers through which the extracellular matrix may influence cell movement, polarity, and gene expression. Changes either in the relative amounts of matrix proteins surrounding hepatocytes ${ }^{2}$ or in the expression of integrins by these cells $s^{3}$ may therefore have profound functional effects.

Matrix proteins accumulate not only because of increased synthesis but also through altered degradation rates. ${ }^{4}$ The principal enzymes concerned in remodelling the matrix are collectively termed metalloproteinases, of which there are three broad groups: interstitial collagenases, stromelysins, and type IV collagenases-gelatinases. Although the last group may have a role in early liver disease, altered interstitial collagenase activity is more likely to contribute to progressive fibrosis. Activity may diminish either because expression of the active enzyme is reduced or because the expression of metalloproteinase inhibitors such as TIMP-1 is increased.

The liver contains few fibroblasts, and until recently the cellular origin of the matrix proteins was uncertain. In vitro culture systems,${ }^{67}$ immunoelectromicroscopy, ${ }^{8}$ and in situ hybridisation ${ }^{9}$ have all been used to show that although hepatocytes can synthesise some matrix proteins, ${ }^{10}$ the main cells concerned are the perisinusoidal cells. ${ }^{11}$ These cells (also referred to as fat storing cells, Ito cells, or lipocytes) lie in the perisinusoidal space of Disse and contain abundant cytoplasmic retinoids. They proliferate in response to liver injury ${ }^{12}$ and undergo phenotypic changes with loss of retinyl esters and hypertrophy of the endoplasmic reticulum. This phenotypic modulation towards myofibroblast-like cells is accompanied by expression of proteins associated with smooth muscle ${ }^{1314}$ and by increased synthesis of matrix proteins. ${ }^{6}$ In most forms of necroinflammatory liver disease activation is mediated by a complex interplay of growth factors, released by Kupffer cells (and possibly platelets)..$^{14}$ Activated perisinusoidal cells may themselves synthesise and secrete some of these peptides, leading to additional autocrine stimulation. ${ }^{\text {is }}$ Other mechanisms, however, may be implicated: acetaldehyde, the toxic metabolite of alcohol, can directly stimulate collagen synthesis in cultured perisinusoidal cells. ${ }^{16}$

Knowledge of the structure and metabolism of the extracellular matrix has led to the development of serum assays which offer a non-invasive approach to assessing hepatic fibrosis. ${ }^{17}$ Concentrations of serum aminoterminal propeptide 
of type III procollagen (PIIIP) correlate with the activity of fibrogenesis, although values are influenced by the degree of hepatic inflammation. This assay is therefore of only limited value during the acute phase of alcoholic liver disease or viral hepatitis ${ }^{17}$ and is no use in children since the high PIIIP values attributable to growth in small children greatly exceed those found in liver disease. ${ }^{18}$ Serum laminin P1 reflects basement membrane turnover and correlates with portal venous pressure in fibrotic liver diseases. ${ }^{19}$ Other potentially useful markers are currently being evaluated. Although the gold standard remains liver biopsy, these serological tests allow fibrogenesis to be monitored over time and may be useful in evaluating new and existing antifibrotic treatments.

Although many drugs used in managing chronic liver disease interfere with the synthesis of matrix proteins - for example, corticosteroids, colchicine, and penicillaminetheir application has been largely empirical. A greater understanding of the mechanisms of fibrogenesis has stimulated the development of more rational approaches. The most promising of these are inhibitors of prolyl 4-hydroxylase, a key enzyme in the biosynthesis of collagen. Identifying compounds which can act as inhibitors only after biotransformation by liver specific enzymes offers an exciting prospect of tissue specific antifibrotic activity. ${ }^{20}$ Other options include manipulating the retinoid content of perisinusoidal cells, ${ }^{21}$ TGF $\alpha$ and TGF $\beta$ antagonists, and compounds which either stimulate interstitial collagenase production or decrease TIMP-1 synthesis. A more speculative but exciting development is of agents which specifically interfere with matrix gene transcription or translation such as antisense RNA. ${ }^{22}$

ALASTAIR D BURT

Senior Lecturer in Pathology,

School of Pathological Sciences,

University of Newcastle upon Tyne,

Newcastle upon Tyne NE1 4LP
Schaffner F, Sieratzki JS. The early history of cirrhosis. In: Boyer JL, Bianchi L, eds. Liver cirrhosis. Lancaster: MTP Press, 1987:57-62.

2 Schuppan D, Somasundaram $\mathrm{R}$, Just $\mathrm{M}$. The extracellular matrix: a major signal transduction network. In: Clément B, Guillouzo A, eds. Cellular and molecular aspects of cirrhosis. INSERM/J Libbey, 1992:115-34.

3 Volpes R, Van den Oord JJ, Desmet VJ. Distribution of the VLA family of integrins in normal and pathological human liver tissue. Gastroenterology 1991;101:200-6.

4 Arthur MJP. Matrix degradation in the liver. Semin Liver Dis 1990;10:47-55.

5 Arthur MJP, Iredale JP, Murphy G, Humbry RM, Friedman SL. Human hepatic lipocytes synthesize and release TIMP-1, an important regulator of matrix metalloproteinase activity. Hepatology 1991;14:183A.

6 Geerts A, Vrijsen R, Burt A, Schellinck P, Wisse E. In vitro differentiation of fat-storing cells parallels marked increase of collagen increase and secretion. $f$ Hepatol 1989;9:59-68.

Friedman SL. Cellular sources of collagen and regulation of collagen production in liver. Semin Liver Dis 1990;10:20-9.

8 Burt AD, Griffiths MR, Schuppan D, Voss B, MacSween RNM. Ultrastructural localization of extracellular matrix proteins in human liver biopsies using ultracryomicrotomy and immunoextracellular matrix proteins in human liver

9 Milani S, Herbst H, Schuppan D, Hahn E, Stein H. In situ hybridization for procollagen types I, III and IV mRNA in normal and fibrotic rat liver: evidence for predominant expression in nonparenchymal cells. Hepatology 1989;10:84-92.

10 Clément B, Rescan PY, Baffet G, Loréal O, Lehry D, Campion JP, et al. Hepatocytes may produce laminin in fibrotic liver and in primary culture. Hepatology 1988;8:794-803.

11 Blomhoff $\mathrm{R}$, Wake $\mathrm{K}$. Perisinusoidal stellate cells of the liver: important roles in retinol metabolism and fibrosis. FASEB F 1991;5:271-7.

12 Geerts A, Lazou J-M, De Bleser P, Wisse E. Tissue distribution, quantitation and proliferation kinetics of fat-storing cells in carbon tetrachloride-injured rat liver. Hepatology 1991;13: 1193-202

13 Tanaka AY, Nouchi T, Yamane M, Irie T, Miyakaw H, Sato O, et al. Phenotypic modulation of lipocytes in experimental liver fibrosis. $\mathcal{F}$ Pathol 1991;164:273-8.

14 Johnson SJ, Hillan KJ, Hines JE, Ferrier R, Burt AD. Proliferation and phenotypic modulation of perisinusoidal (Ito) cells following acute liver injury: temporal relationship with TGF $B_{1}$ pexpression. In: Clement B, Guillouzo A, eds. Cellular and Molecular Aspects of Cimhosis. INSERM/J Libbey, 1992:219-22.

15 Gressner AM, Bachem MG. Cellular sources of noncollagenous matrix proteins: role of fat-storing cells in fibrogenesis. Semin Liver Dis 1990;10:30-46.

16 Casini A, Cunningham M, Rojkind M, Lieber CS. Acetaldehyde increases procollagen type I and fibronectin gene transcription in cultured rat fat-storing cells through a protein synthesisdependent mechanism. Hepatology 1991;13:758-65.

17 Schuppan D. Connective tissue polypeptides in serum as parameters to monitor antifibrotic treatment in hepatic fibrogenesis. I Hepatol 1991;13:S17-S25.

18 Triveldi P, Cheeseman P, Portmann B, Mowat AP. Serum type III procollagen propeptide as a noninvasive marker of liver damage during infancy and childhood in extrahepatic biliary atresia, idiopathic hepatitis of infancy and $\alpha 1$ antitrypsin deficiency. Clin Chim Acta 1985;161:137-46.

19 Gressner AM, Titton W, Negwer A, Pick-Kober KH. Serum concentrations of laminin and aminoterminal propeptide of type III procollagen in relation to the portal venous pressure of fibrotic liver diseases. Clin Chim Acta 1986;161:249-58.

20 Bichel M, Baader E, Brocks DG, Engelbart K, Günzler V, Schmidts HL, et al. Beneficial effects of inhibitors of prolyl 4-hydroxylase in $\mathrm{CCl}_{4}$-induced fibrosis of the liver in rats. 7 Hepatol 1991;13:S26-S34

21 Pinzani $M$, Paolo G, Abboud HE. Phenotypical modulation of liver fat-storing cells by retinoids. Influence on unstimulated and growth factor-induced cell proliferation. $f$ Hepatol 1992;14: $211-20$

22 Chojkier M, Brenner DA. Therapeutic strategies for hepatic fibrosis. Hepatology 1988;8:176-82.
Unexpected sudden death in fit young people is distressing; but if the death is explicable the family may be able to begin the process of psychological adjustment. The pathologist has, then, an obligation to explain the death and should follow a logical approach.

Firstly, unnatural death has to be excluded, largely on the basis of the investigation by the coroner's officers. Misuse of solvents or cocaine, for example, is associated with sudden death.

Secondly, extracardiac causes are excluded. Thirdly, the heart is examined for conditions associated with sudden death. Between the ages of 40 and 69 coronary atherosclerosis is the cause of $65 \%$ of sudden deaths in men and $40 \%$ in women. ${ }^{1}$ Coronary atherosclerosis is a rare direct cause of death in younger age groups, but pathologists do see coronary thrombosis in the third decade. Pathologists need to draw a distinction between the presence of atherosclerosis, which is virtually universal in Western populations from an early age, and coronary heart disease as a cause of death. Further evidence is required for their diagnosis - high grade stenosis, thrombosis, or old or recent infarction.

Several other cardiac conditions are known to be associated with sudden death. Hypertrophic cardiomyopathy is still underdiagnosed at necropsy owing to its protean macroscopic appearances. ${ }^{3}$ The diagnosis must be excluded positively by histological examination. Right ventricular dysplasia is another familial cardiomyopathy strikingly associated with death on exercise in fit people. ${ }^{45}$ The fully developed condition, in which the right ventricular wall is totally replaced by fat and fibrous tissue, is easily recognised. Study of affected families has shown, however, that sudden death can occur at an earlier stage, when recognition at necropsy is difficult.

Left ventricular hypertrophy of more than $50 \%$ by mass is associated with sudden death in its own right. Furthermore, histological examination of the myocardium should be undertaken in all cases to exclude myocarditis and fibrosis as causes of arrhythmias.

Abnormalities of the coronary. arteries associated with sudden death include one ostium arising in the pulmonary artery ${ }^{6}$ and spontaneous dissection of a coronary artery, which occurs much more commonly in women than men. ${ }^{7}$

A small subset of patients with prolapse of the mitral valve have palpitations and may die suddenly. ${ }^{89}$ Given the total number of people with mitral prolapse, the risk must be very low, but if no other cause of death is found at necropsy the 